\title{
ISSUES WITH CLASSIFICATION \\ AND CATEGORIZATION OF ACCOMMODATION IN POLAND AND IN THE EU
}

\section{MAŁGORZATA KOZŁOWSKA}

\begin{abstract}
Pedagogical University of Cracow, POLAND
e-mail: mkozlowska@up.krakow.pl

RECEIVED

1 February 2016

ACCEPTED

1 June 2016

JEL

CLASSIFICATION

Z32

KEYWORDS

hotel business, hotels categorizing systems, Hotelstars Union system

ABSTRACT

Hospitality services market is one of the fundamental branches of tourist economy. In the era of globalization that is characterized by striving to homogenization and unification, lack of standardized categorization system of accommodation facilities in Europe and in the world is surprising. Therefore, an analysis of existing categorization systems in different countries and EU regulations is necessary. Results of the research show that the hotel industry recognizes the need for classification of accommodation facilities and aspires to work out a standardized system. Hotelstars Union is an association that proposed their own classification system that allows to accurately inform customers about the standard of the facility, leading to an increase in the transparency of the whole industry. Polish hoteliers have to decide whether to update and correct the out-dated Polish system or to join the HU system.
\end{abstract}

\section{Introduction}

Market for hospitality services is one of the most essential and increasingly lucrative branches of tourist economy (Milewska, Włodarczyk, 2009). Global potential of hospitality market at the turn of the 21st century was estimated at 13 million rooms, 73\% of which were located in Western Europe and North America. In February 2012, it was estimated to be 13,5 million rooms in 90 thousand hotels (report STR Global, 2015). However, data 
published by research companies and so-called independent experts from USA and UK are very different (even 19-52.5 million rooms in 130-550 thousand hotels) from the numbers listed above. This could be caused by lack of a global, uniform definition of a hotel, and a unified classification of accommodation (e-hotelarstwo, 2012). In Poland, there were 10,024 tourist accommodation facilities in 2015 including 3,723 categorised hotels, motels and pensions (2,316 hotels) and 6301 other accommodation facilities such a youth hotels, hostels, inns, B\&B.

After joining the EU, Poland made a commitment to adapt the law, including tourist law, to the EU standards. Taking advantage of the unified market of the EU, i.e. free flow of products and services, Polish hoteling made its mark on the European market. In terms of hoteling services, categorization system of accommodation is a significant element that facilitates the comparison of quality of services and protects the consumer. One could assume that in the age of globalization, which manifests itself by striving to standardize services and unify the EU market, hoteliers would have worked out a uniform categorization system. Meanwhile, the diversity of classification and categorization systems of accommodation facilities used in different countries makes this task much harder.

\section{Aim of the studly}

The objective of this study was to compare current Polish system of classification and categorization with the Hotelstars Union system, as well as obtain opinions of Polish experts in the field of hoteling. Furthermore, the aim was to determine the advancement of the modification of the existing accommodation categorization system in Poland, and to find possible improvements.

To achieve these aims, a survey and direct interviews were conducted. In 2015 hoteliers and representatives of administration responsible were surveyed for categorization in Poland. Surveyed facilities were chosen randomly (total of 122) in Cracow (99) and Zakopane (23), including: 88 hotels (in categories: ${ }^{*} 4,{ }^{* *} 16,{ }^{* * *} 42,{ }^{* * *} 18,{ }^{* * * * *} 8$ ), 2 motels, 2 pensions, 2 youth hostels, and 28 others ( 4 student houses, 15 hostels, 4 holiday resorts, 5 private guest houses). These were represented by 15 owners, 10 presidents, 25 managers and 72 employees.

Simultaneously, a set of questions was sent out via email to 39 central and local administration units, i.e. Ministry of Sport and Tourism, Marshall Offices, Polish Tourist Organization, hoteling associations (Polska Izba Hotelarstwa - PIH, Polskie Zrzeszenie Hoteli - PZH, Izba Gospodarcza Hotelarstwa Polskiego - IGHP, Polska Izba Turystyki - PIT, Polskie Towarzystwo Schronisk Młodzieżowych - PTSM, Instytut Hotelarstwa - IH).

\section{Categorization of accommodadtion in Europe}

Categorization ranks hotel establishments according to set criteria and standards. Due to cultural differences, there are many categorization systems in use, which are dependent on many factors, e.g. tradition, development of tourist infrastructure, size of tourist market, distribution of tourist goods (Szostak 2008; Pierret, 2013). Quality of services, reception, equipment, accommodation, toilets, gastronomy, and professionalism of the staff are graded in the categorization process. To date, EU has not developed a unified, standardized categorization system of accommodation facilities (Table 1).

There is no categorization of hotels in Finland and Norway. In Italy and Spain, each region has its own system. In other countries, the classification is regulated differently, i.e. through different administrations or associations (Table 1). A majority of countries apply a public classification system, but in 10 classification system was administered by hotel organizations. Countries where classification of hotel enterprises is optional have a higher average GDP per capita than those where classification is compulsory (Pawlicz, 2014). 
Issues with classification and categorization of accommodation in Poland and in the EU

Table 1. Accommodation categorization in selected European countries

\begin{tabular}{|c|c|c|c|c|c|c|}
\hline Country & $\begin{array}{c}\text { Official } \\
\text { classify-cation }\end{array}$ & $\begin{array}{l}\text { Nationwide } \\
\text { or regional }\end{array}$ & $\begin{array}{l}\text { Obligatory } \\
\text { or optional }\end{array}$ & $\begin{array}{l}\text { Criteria set by } \\
\text { administration }\end{array}$ & $\begin{array}{c}\text { Classified } \\
\text { by administration }\end{array}$ & Financed by \\
\hline Finland & NO & - & - & - & - & - \\
\hline France & YES & nationwide & optional & central & & hotelier \\
\hline Ireland & YES & nationwide & optional & Tourist Board & $\begin{array}{l}\text { Tourist Board through Tourist } \\
\text { Quality Services }\end{array}$ & $\begin{array}{l}\text { Tourist Board (funded by } \\
\text { the hoteliers) }\end{array}$ \\
\hline Italy & YES & regional & obligatory & regional & local & public funds \\
\hline Norway & NO & - & - & - & - & - \\
\hline Poland & YES & nationwide & obligatory & central & regional & hotelier \\
\hline Portugal & YES & nationwide & obligatory & DGT - central & DGT - central & public administration \\
\hline Spain & YES & nationwide & obligatory & regional & regional & \\
\hline UK & YES & $\begin{array}{c}\text { Nationwide - } \\
\text { different in England, } \\
\text { Scotland and Wales }\end{array}$ & optional & central & $\begin{array}{l}\text { central and local authorities } \\
\text { Tourist boards }\end{array}$ & $\begin{array}{l}\text { subscription paid by the } \\
\text { hoteliers }\end{array}$ \\
\hline \multicolumn{6}{|c|}{$\begin{array}{l}\text { Austria, Belgium, Czech Republic, Denmark, Estonia, Germany, Greece, Hungary, Lithuania, Luxembourg, Latvia, } \\
\text { Malta, Netherlands, Sweden, Switzerland }\end{array}$} & Hotelstars Union System \\
\hline
\end{tabular}

Source: own interpretation based on ECC-Net 2009 and HSU data.

Hoteling entrepreneurs and members of hotelier associations had noticed the need to standardize these regulations. The question is: if the new, universal categorization system developed by the Hotelstars Union association could be the solution to this vast issue. According to Minazzi (2010) the definition of European minimum requirements should be a step process. First of all countries should continue the present trend of standardizing internal criteria and quality standards at a national level, especially where there are strong differences among regions and, then, it could be possible to proceed with the European harmonization.

\section{Hotelstars Union Classification System}

Hotelstars Union (HU) is a non-profit organization under the auspices of HOTREC. This initiative is aimed at European countries that wish to improve the quality of hospitality services and efficiency of the marketing. The association was established in 2009 by self-regulatory organizations of founder countries: Austria, Czech Republic, Germany, Hungary, Netherlands, Sweden and Switzerland. Next counties joined: Luxembourg, Lithuania, Latvia, Estonia (2011), Malta (2012), Belgium, Denmark, Greece (2013). Poland has not yet joined, however it participated in initial efforts. Currently, France has observatory status, and Spain is considering joining. HU system is used in 15 countries (Table 1) to provide unified categorization and direct access to the common market by facilitating comparison of price and quality of service. This classification is based on 270 criteria (Polish system only has 120 criteria) and a point system. Some of these criteria are essential, while others allow to collect additional points. They are focused on the management of quality and comfort of stay, and range from very basic to surprisingly bizarre. A hotel can get a maximum of 860 points basing on the comfort of sleep, cleanliness and quality of service. Categorization is fairly elastic and cannot be easily disqualified if an element is missing. Hotels in a given category, which have a significant surplus of points, get a title 'Superior'. The system distinguishes between hotels and garni hotels (Table 2), which only serve breakfasts. Requirements for garni hotels are the same, but they have a lower point threshold ( 20 points less) and they cannot have 5 stars. 
Table 2. Criteria and points used in HU system

\begin{tabular}{cccccccc}
\hline Category & $\begin{array}{c}\text { Min. no of points/ } \\
\text { criteria }\end{array}$ & Category & $\begin{array}{c}\text { Max. additional } \\
\text { points }\end{array}$ & Category & $\begin{array}{c}\text { Min. no of points/ } \\
\text { criteria }\end{array}$ & Category & $\begin{array}{c}\text { Max. additional } \\
\text { points }\end{array}$ \\
\hline $1^{*}$ & $90 / 44$ & $1^{*}$ superior & 80 & Garni $1^{*}$ & $70 / 44$ & Garni $1^{*}$ Superior & 80 \\
$2^{*}$ & $170 / 53$ & $2^{*}$ Superior & 80 & Garni 2* & $150 / 53$ & Garni 2* Superior & 80 \\
$3^{*}$ & $250 / 83$ & $3^{*}$ Superior & 130 & Garni $3^{*}$ & $230 / 83$ & Garni $3^{*}$ Superior & 130 \\
$4^{*}$ & $380 / 104$ & $4^{*}$ Superior & 190 & Garni 4* & $360 / 104$ & Garni 4* Superior & 190 \\
$5^{*}$ & $570 / 120$ & $5^{*}$ Superior & 80 & & & & \\
\hline
\end{tabular}

Source: own interpretation basing on official information from the www.hotelstars.eu.

In HU countries, self-regulatory organizations or hoteling associations are responsible for the categorization. According to TNS Institute in Germany, $47 \%$ of respondents chose an HU hotel (survey commissioned by Deutscher Hotel- und Gaststättenverband - in 2014). This indicates that customers appreciate and trust the HU system (Table 3).

Table 3. Question: What information do individual tourists take into account when choosing a hotel? (\%)

\begin{tabular}{lcc}
\hline \multicolumn{1}{c}{ Information source } & 2008 & 2014 \\
\hline Direct recommendation & 67 & 74 \\
Online reviews & 26 & 52 \\
Official 'hotelstars' & 41 & 47 \\
Certificates obtained by the hotel & 10 & 27 \\
Hotel brand & 29 & 16 \\
\hline
\end{tabular}

Source: TNS Infratest, data collected on 24-25.06.2014, $n=1014$.

It is worth noting that Hotelstars Union is only used to categorize hotels. The HU system does not solve the issue with categorization of other facilities, such as hostels, guest houses, campings, etc. However, the question remains whether there is a need to categorize these establishments at all.

\section{Accommodation categorization system in Poland}

Current categorization system in Poland is strictly regulated by the Act on Tourist Services. The Directive of the Minister of Economy and Employment of August 19th 2004 (with later changes in 2011 and 2015) lists requirements for different types and stars. The minimum quality requirements include external equipment (e.g. lighting), internal features (heating, sewage, air conditioning, elevators, etc.), reception and gastronomy (e.g. minimum surface area, amount and standard of toilets), minimum range of services provided (e.g. wake-up calls), minimum area of the rooms, furnishing, sanitary facilities, minimum qualification of the personnel.

Creators of the Act define hotel services as 'short-term, generally accessible rental of houses, apartments, rooms, campsite places, and providing related services within the establishment. These services can be provided in hotel facilities and others'. Classification distinguishes between types of facilities that provide a similar range of services: hotels, motels, pensions, youth hostels, tourist houses and camping sites. Each establishment also 
is assigned to a category dependent on its standard. Hotels, motels and pensions have a 1-5 star scale, campings 1-4 stars, youth hostels and tourist houses - roman numerals I-III. Assignment of the type and category is voluntary, on request of the entrepreneur providing hotel services.

\section{Results and discussion}

Initially, only Polish hoteliers were surveyed. The analysis shows that $81 \%$ of the representatives knew that the public administration is responsible for the categorization of accommodation in Poland, while $14 \%$ answered incorrectly (hotelier associations), and $5 \%$ abstained from answering (Figure 1).

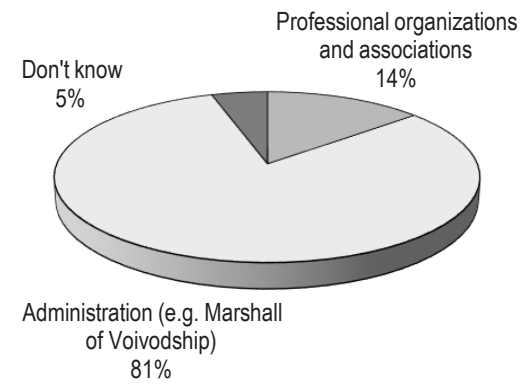

Figure 1. Who is responsible for categorization of accommodation in Poland? Survey results - answers of hoteliers Source: own study.

Only $13 \%$ admitted that the current system is not adequate, while $65 \%$ are in favour of this system and $22 \%$ of respondents had no opinion on the matter (Figure 2). An alarming high percentage (91\%) of the respondents does not know the Hotelstars Union system, currently used in 15 countries (Figure 3). Therefore, it is not surprising that the majority (90\%) does not know whether Poland should join this system (Figure 4).

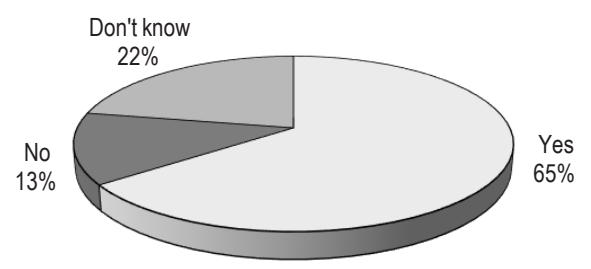

Figure 2. Is the current categorization system of accommodation adequate? Survey results - answers of hoteliers Source: own study. 


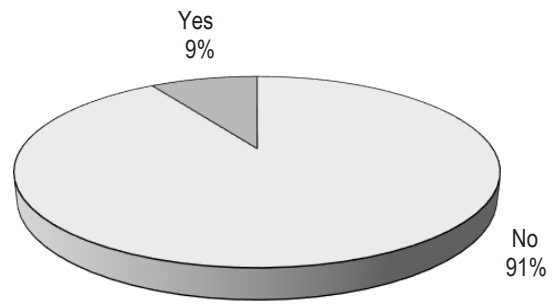

Figure 3. Do you know Hotelstars Union categorization system? Survey results - answers of hoteliers

Source: own study.

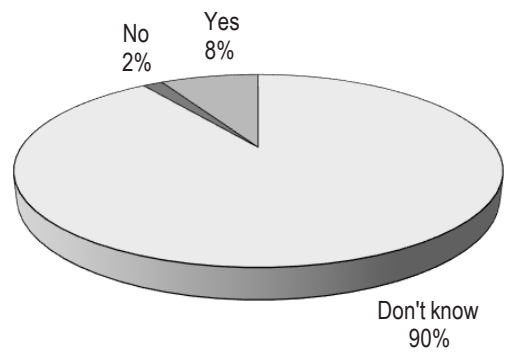

Figure 4. Do you think Poland should join the Hotelstars Union system? Survey results - answers of hoteliers Source: own study.

Only $8 \%$ of the representatives of the hospitality industry thinks that implementing a uniform categorization system would improve the quality of services provided and unify the Polish market with the European market.

Hoteliers associated with Polish Hoteling Chamber of Commerce (IGHP) - currently ca. 5\% of all hoteling enterprises - strive to introduce Hotelstars Union system. According to them, replacing the current archaic system with the $\mathrm{HU}$ system could increase the number of hotels in Poland by a 1000. Furthermore, it would increase the number of foreigners staying in hotels that do not belong to global chains or franchise (e-hotelarz 2014). Ministry of Sport and Tourism has assured on multiple occasions that they plan to begin work on the new tourism regulations, but these efforts have never begun. Hoteliers suspect that the Ministry is not interested in changing the system, but rather in the evolution of the current system. When planning extensive changes, it is important to consider their implications, as well as the regulations of Hotelstars system. According to president of MIHH Gremium, the current categorization act is not appreciated amongst the hoteliers, and central governing of the number of 'hangers in the closet' is ridiculous. When surveying the administration and professional units, a significant variance was found. President of Polish Chamber of Commerce (PIH) states that is in favor of implementing the HU system. Moreover, $\mathrm{PIH}$ will provide Polish hoteliers with information on $\mathrm{HU}$ during training courses. Meanwhile, president of $\mathrm{IH}$ claims that revision of the Polish system is necessary, but it should happen by the change in law. The IH realizes that quality parameters should be implemented rather than focusing solely on the quantitative measures. Categorization requirements should not only define what (e.g. carpet), but also what quality (e.g. minimum $14 \mathrm{~mm}$ carpet) is 
necessary. Furthermore, the $\mathrm{IH}$ does not see the need to join $\mathrm{HU}$, as it might lower the categorization standards. Representatives of the Marshall Offices and the Ministry of Sport and Tourism affirm that the current, state-regulated system ensures impartiality and reliable categorization. Additionally, it protects the consumers and facilitates the provision of hotel services by the entrepreneurs. Some hoteliers claim that excessive interference in the market through substantial regulations will limit the freedom of hoteliers. The data shows that both administration (Ministry of Sport and Tourism, Marshall Offices) and professional associations (chambers of commerce, federations, etc.) are not involved in any consultations or communications with hoteliers regarding the changes in the Polish categorization of accommodation facilities and the HU system.

\section{Conclusions}

The easiest way for the consumers to take advantage of the common market is through comparison of prices and services in the EU, and eventually in the world. Meanwhile, the vast diversity of classification systems impedes the unification of the market, and hinders estimations of number of hotels and, therefore, number of rooms available in a given country or in the world. Hence in the era of globalization of production and services, introducing a global categorization of accommodation system seems to be a necessity, not a choice.

Hotelstars Union system has the potential to solve the issues regarding the subjectivity of evaluation of the accommodation facilities and services they provide. Therefore, instead of updating and correcting the out-dated Polish system, maybe it is worthwhile to join the HU system and become an active member to ensure that the needs of Polish hoteliers and consumers are taken into account. Joining the HU system could help Poland to become more competitive on the common EU market, especially for the hotels not belonging to chains, and eventually to lower prices. However, it is alarming that the majority of Polish hoteliers was not aware of the existence of the HU system, does not know its regulations and is not able to evaluate its practicality. Lack of professional consultations and informative campaigns concerning the increasingly popular Hotelstars system can result in missing out on the benefits provided by the common European market. On the other hand, Hotelstars Union defines categorization requirements only for hotels, while the Polish system lists 8 types of accommodation. Hence, joining the HU system would entail discontinuation of the categorization of other types of accommodations. The question remains whether there is a need to classify and categorize other accommodation establishments, and which ones. Furthermore, there is a significant difference in opinion amongst the professional associations and administrative units.

It appears that in the future, social media will have a significant impact on how hotels are selected and reviewed (Hensens 2015) as they provide integration of data for both hotels and consumers, and allow the rating bodies to respond to the changing environment. Therefore, it is justified to investigate this issue further to determine the expectations and needs of consumers in terms of clear information on the standards of accommodation. Consumers should determine the modern categorization requirements. To date, no administration or professional organizations in Poland are carrying out such research.

\section{References}

Act of 29 August 1997 on tourist services (Dz.U. 1997, nr 133, poz. 884).

Classification of hotel establishments within the EU. Available at: http://www.europe-consommateurs.eu/fileadmin/user_upload/euverbraucher/PDF_Englisch/Reports.pdf (15.05.2015).

Directive 90/314/EWG of 13 June 1990 on international travel and tours (OJEC L 158 of 23.06.1990). 
Directive of August 19th 2004 (Dz.U. 2006, nr 22, poz. 169) and later changes (Dz.U. 2011, nr 259, poz. 1553; Dz.U. 2015, poz. 1626). Hensens, W. (2015). The future of hotel rating. Journal of Tourism Futures, 1 (1), 69-73.

Milewska, M. \& Włodarczyk, B. (2009). Hotelarstwo, Podstawowe wiadomości. Warszawa: PWE.

Minazzi, R. (2010). Hotel classification systems: a comparison of international case studies. Acta Universitatis Danubius, CEconomica, 64-86.

Panasiuk, A. \& Szostak, D. (2009). Hotelarstwo - usługi - eksploatacja - zarządzanie (pp. 118-128). Warszawa: Wydawnictwo Naukowe PWN.

Pawlicz, A. (2014). Determinanty systemu kategoryzacji przedsiębiorstw hotelarskich w krajach Unii Europejskiej. In: Turystyka wobec zmian współczesnego świata: strategie, marketing, programowanie (pp. 312-325). Poznań: Wydawnictwo Uniwersytetu Ekonomicznego.

Pierret, F. (2013). About hotel classification systems. Available at: http://cf.cdn.unwto.org/sites/all/files/hotel_classification_systems. pdf (25.07.2015).

Światowy rynek hotelowy wg STR Global, 2014-09-14. Available at: http://www.e-hotelarstwo.com/aktualnosci/ dossier?more=1740262663 (15.05.2015).

Szostak, D. (2008). Hotelarstwo i gastronomia. In: A. Panasiuk (ed.), Gospodarka Turystyczna. Warszawa: Wydawnictwo Naukowe PWN.

Turystyka w 2015 r. Warszawa: Główny Urząd Statystyczny.

UNWTO Annual report 2014. Tourism's contribution to trade. Available at: http://dtxtq4w60xqpw.cloudfront.net/sites/all/files/pdf/unwto_ annual_report_2014.pdf (30.07.2015).

Cite this anticle aS: Kozłowska, M. (2016). Issues with classification and categorization of accommodation in Poland and in the EU. European Journal of Service Management, 19 (3), 43-50. DOI: 10.18276/ejsm.2016.19-06. 